\title{
The Public Perception of The Development of River of Life Area as A Tourist Attraction in Kuala Lumpur
}

\author{
*Melisa Rona Fitri ${ }^{1}$ and Nurasyiqin Binti Harmainis ${ }^{2}$ \\ 1) Graduate Student of Geography Education, Universitas Negeri Padang, Indonesia \\ e-mail: melisaronafitri92@gmail.com \\ 2) Student of Geography, Malaya University, Malaysia \\ e-mail: ekinasyikin96@gmail.com
}

*Corresponding Author, Received: September 14, 2018, Revised: October 21, 2018, Accepted: December 05, 2018

\begin{abstract}
The purpose of this study was to determine the public's perception of the development of the River of Life area as a tourist attraction in Kuala Lumpur. This type of research is descriptive qualitative research that uses observation, interviews and documentation as data collection instruments. Sampling Technique using Accidental Sampling technique. While the data source consists of primary data obtained directly in research in the field. The results of this study found: 1) Public perception of the development of the River of Life area as one of the tourist attractions in Kuala Lumpur is very good. Because, River of Life revitalizes the old environment, increases the historic attractiveness of the city, provides an effective transformation network to ensure a pleasant journey for residents and tourists. 2) Public perception of access to River of Life is very good. 3) Community perception with the development of the River of Life area is very good because it can open up new opportunities and jobs for the local community. River of Life provides affordable housing for more than 35,000 new residents, one million square meters of commercial space, more than 27,000 new job opportunities, increased using of public transportation. 4) Community perception of the uniqueness of the River of Life area as a tourist attraction is that there is one component of the River of Life project, namely the Blue Pool or Blue Poll which is the River Beautification Project located next to the Sultan Abdul Samad Building.
\end{abstract}

Keywords: Perception, Development, River Of Life

\section{Introduction}

Tourism is one of the largest industries in the world that is growing rapidly (Moli, 2011; Hermon, 2016a). Tourism is a very important economic centre because the income from these activities is very high (Ghanapala, 2015; Hermon, 2016b). Tourism is considered as an industrial sector that is able to develop the independence of a country and is a driver of growth in other sectors (Nugraha et al., 2013). This makes tourism an icon of development in a country whose development is increasing. Tourism touches various aspects of people's lives, including socio-economic, socio-cultural and environmental aspects. In addition, the tourism industry is not only related to tourist attractions but also related to other industries, such as hotels, restaurants, transportation (land, sea and air) and other industrial products (Tjitroresmi, 2003; Hermon, 2010a; Hermon, 2012). As it was previously explained, tourism is a "new" commodity for countries in the world, especially for developing countries.

Tourism development is an important strategy as an important effort to improve economic development (Umar, 2017; Hermon, 2015; Hermon, 2017). Where at the time the various economic sectors 
of developing countries were focused on various activities of enrichment and exploration of natural wealth. In general, when developing countries must develop their economic sectors to get better state income, tourism is the right choice where every country will always have the distinctive characteristics and attractiveness for foreign and domestic tourists (Hermon, 2009; Hermon, 2010b).

Kuala Lumpur was a country that at the beginning of its independence in 1960 focused economic activities on the agricultural and mining sectors, but this industry began to decline in 1970 (Walton, 2009). As Richter said about the need for the development of social and economic development of countries in the world, then the idea that tourism can become an indicator for the development of social and economic development (Richter, 1980). Kuala Lumpur as one of the tourist destinations that has a special attraction for tourists to visit, one form of tourist attraction is the natural wealth and indigenous culture of Malaysia, namely the culture of ethnic Malay and various ethnic minorities that exist and are scattered in various regions of the city - small town, rural, and inland Malaysia. But this has not been supported by infrastructure and good access (Dinnie, 2008). But what needs to be understood is that Malaysia does not simply have readiness in its tourism industry.

Various development processes and maturing tourism in Malaysia are carried out for example by the existence of Project River of Life. Rivers are an important part of tin mining transportation. The arrival of the Klang River that we know today has been a bad sight for years, underestimated because of its muddy and toxic water and excessive accumulation of garbage, especially because of its location in the heart of a densely populated city whose residents are not reluctant to use their waters as trash bins. It is also vulnerable to flash floods caused by erosion of the surrounding soil Efforts have been made for years to clean it up, with little or no real success, until now. Seeing the potential of what is known as a possible "most exploited underground natural asset" in Kuala Lumpur, the River of Life project has been identified as an Entry Point Project in the Kuala Lumpur / Klang Valley (NKEA) National Key Economic Zone under the Transformation Program Economy (Segaren, 2015). Project River of Life is one of the first projects under the economic transformation program for Greater Kuala Lumpur, aiming to transform the Gombak River and Klang River into a dynamic and livable waterfront icon through three main components, namely river cleaning, river removal as a tourist attraction and land development.

Through this project, the Kingdom has carried out various river cleaning initiatives such as raising the level of the containment system, adding trash traps along the river and introducing the Interceptor system (Rajak, 2017). Project River of Life involves several historic heritage buildings for Kuala Lumpur, such as the Masjid Jamek Sultan Abdul Samad and the Building of Sultan Abdul Samad. The Kingdom also maintains the buildings of Malaysia's heritage by increasing existing levels of structure and increasing public accessibility to the surrounding areas. For example, this River of Life involves increasing the level of Masjid Jamek Sultan Abdul Samad by combining Islamic elements and motives in the form and transfer of its parks, including the addition of 4,400 square feet of solar space for the comfort of more than 1,000 worshipers. Accessibility to Masjid Jamek Sultan Abdul Samad is also enhanced by fostering pedestrian bridges connecting the mosque with the buildings of Sultan Abdul Samad and Dataran Merdeka which can shorten the travel period. (Rajak, 2017). In the middle, precisely in the part that borders the highway, a plaza or open public space is also built. Many people took photos of the Jamek Mosque called Jamek Lookout Point Mosque. Around the Jamek Mosque, where the Klang River and Gombak River meet, there are fountains that radiate from various directions (Bidasari, 2018; Hermon et al., 2018).

\section{Method}

The purpose of this study was to find out about: a) Public perception of the development of the River of Life area as one of the tourist attractions in Kuala Lumpur. b) Community perception of road access to the River of Life. c) Community perceptions with the development of the River of Life area can open up new opportunities and jobs for the local community. d) Public perception about the uniqueness of River of Life as a tourist attraction. This research was conducted in July in Kuala Lumpur. The type of data in this study is qualitative data. The qualitative data in this study is data obtained from interviews with resource persons (Hermon et al., 2008). While the data source consists of primary data obtained directly in the field research as a result of direct observation in the field and through interviews with resource persons (Kusmayadi and Endar, 2000). Sampling Technique, in this study using Accidental Sampling technique, 
namely sampling obtained based on the chance to meet in the research location when searching for data, and the person who happened to be found was suitable as a data source. Data Analysis Techniques, in this study data analysis techniques in the form of qualitative descriptive analysis, were collected by interview method.

\section{Results and Discussion}

Tourism is one of the important sectors in the economy of the Malaysian State which later became the fifth largest sector in Malaysia in 2010 based on the State Design Unit. Although at the beginning of independence the kingdom had not yet glanced at this sector, because at that time the kingdom was more focused on developing the country's infrastructure and resisting threats from communists (Mahmud, 2009). It was only in the 70s that the tourism sector experienced a positive development, this was marked by the arrival of tourists to Malaysia which increased from 23,000 in 1961 to 77,000 in 1970. The latest data in 2005 tourist arrivals to Malaysia again increased where as many as 16,4 million people were recorded as coming to Malaysia. In the Big Indonesian Dictionary, development is defined as a process or a way to make it progress, good, perfect and useful (Poerwadarmita, 2003). In principle, tourism development begins with an inventory of tourism treasure sources to identify realistic evaluations of existing or potential this right is an integral part of the preliminary and planning stages. Development is to advance and improve or improve existing ones (Lanya, 1995). The book of "Introduction to Tourism Science" that told about the term tourist attraction is more commonly used, namely everything that attracts people visiting a particular area (Yoeti, 1985). Meanwhile, according to the book "Science of Tourism" in 1994, defining tourist attraction as everything that is interesting and valuable to visit and see (Nyoman, 1994). And then there are several limitations on tourist attraction with several criteria in a tourist attraction, namely: 1) The existence of resources that cause pleasure. 2) There is good accessibility to reach tourist attractions. 3) There are specific or specific characteristics. 4) There are supporting facilities and infrastructure that can serve the needs of tourists who come. 5) Natural attractions that have high attraction due to the natural beauty of mountains, sand, forests, and so on. 6) Tourism objects have a high attraction because they have special values in the form of art attractions in a tourist attraction created by humanity in the past (Suwantoro, 2001). In accordance with the results of research that has been carried out related to the public perception of the development of the River of Life area as one of the tourist attractions in Kuala Lumpur which is carried out from 6 July 2018 to 12 July 2018 in the City of Kuala Lumpur, Malaysia. Based on interviews conducted following the results or facts that the researchers found related to people's perception of the development of the River of Life area as one of the tourist attractions in Kuala Lumpur. People strongly agree with the development of the River of Life area as one of the tourist attractions. Initially River of Life was a project started in 2011 which aims to improve river water quality from Class III and Class IV (not suitable for body contact) to Class IIB (suitable for body contact and recreational use), then under the Irrigation Department and Drainage Malaysia, which leads the river cleaning initiative, is supported by more than 20 institutions in four Ministries and two Selangor regional governments are developing. One of them is for travel. This project educates the public about the importance of environmental awareness, this will slowly begin to be implemented in Malaysia. River of Life besides revitalizing the old environment, it also aims to increase the attractiveness of the city's history, by providing an effective transformation network to ensure a pleasant journey for residents and tourists. Coupled with the introduction of a blue pool multifunctional infrastructure to revitalize existing developments. Providing a unique experience of forming cooling and aesthetic effects from fountains and fogging systems encourages the experience of touching blue water which is processed through an interceptor system under the river cleaning component which will increase the focal point of the Jamek mosque.

The development of the River of Life area as a tourist attraction will have a positive impact on the development of tourism in Kuala Lumpur because it will add to the tourist attraction in Kuala Lumpur. Being the hope of the community through this project, the area around the Klang River and the Gombak River will be presented as a tourist attraction area that is comparable to a city like Melbourne, Seoul and Singapore which have an iconic and attractive waterfront. Thus, it will definitely attract a large number of competitive investments and provide many economic opportunities, which can serve the people well. Therefore, the community strongly agreed and gave a positive response to the development of the River of Life area as one of the tourist attractions. 
Public perception of access to the road to River of Life is very good. Accessibility is often associated with transportation costs and locations that are rarely visited usually have more expensive costs. (Pike, 2004). States accessibility refers to the ease that visitors can get to travel and enter a place (March 2004). Then accessibility also can be an attribute for people (and goods) not transportation capital or the availability of services and explains the integrated system from the user's point of view" (Halden, Jones and Sarah, 2005). Judging from the telecommunication system around the River of Life area, it runs very well, the internet network is already fast enough. And we can find many places in the River of Life area that provide free internet facilities with a wifi system with internet access that is very easy so that to find the latest information they can find it only with a smartphone. Through this project, the Kingdom has also maintained the buildings of the country's heritage by increasing the existing level of structure and increasing people's accessibility to the surrounding area. Accessibility to Masjid Jamek Sultan Abdul Samad was also enhanced by a pedestrian bridge that connects the mosque with the buildings of Sultan Abdul Samad and Dataran Merdeka which can shorten the travel time from before. To take the River of Life visitors can choose various travel routes. Visitors can start from the guide gallery in Leboh Besar Market on this route, we will surround the buildings and places of interest around the River of Life. Visitors can also go through the colonial road, through the Week of China or the Cultural Path or visitors can also take the LRT to the Pasar Seni Station. From there, visitors can walk along the banks of the Klang River to the Jamek Mosque. This will make it easier for visitors to travel to the River of Life. It can be concluded that access to the River of Life area is good.

Community perceptions with the development of the River of Life area can open up new opportunities and jobs for the local community. The reason, the local community is very happy with the development of the River of Life area as a tourist attraction because it will be able to open new jobs for the local community. Coupled with the existence of royal cooperation with the private sector to facilitate the increase of tourism, namely by setting up lodging or hotels, and increasing the lodging also provides employment opportunities for residents around the River of Life area. The main hope of the local community with the development of the attraction of River of Life tourism can increase the economic community from those who used to work as labourers and traders until those who have not worked or unemployed can switch professions in the tourism sector. The success of tourism development, in the long run, depends on the attitude of the local community and other stakeholders on tourism and tourists. Therefore tourism development must consider the needs and desires of the community (Andriotis, 2005). Through this initiative, the government will build parks, pedestrian paths, cycling paths, to commercial functions (shops, hotels, restaurants and residences) along the Klang River flow. Moreover, the Klang Valley region which covers all of Kuala Lumpur, Selangor, parts of Negeri Sembilan, and a bit of Perak State is the 4th largest basin in Malaysia. River of Life will provide affordable housing for more than 35,000 new residents, one million square meters of commercial space, more than 27,000 new employment opportunities, increase use of public transportation in the master plan area from 15 per cent to $60 \%$ and reduce demand traffic by 15 percent in 2020 (Malaysia's Irrigation and Drainage Positions, 2018).

Public perception of the uniqueness of River of Life as a tourist attraction is very different from the others and very unique. River of Life (ROL) or Sungai Nadi Kehidupan Project is one of the Kingdom Guild projects for maintaining the river and its surroundings. One component of the River of Life project is the Blue Pool or Blue Poll which is the River Beautification project which is located next to the Sultan Abdul Samad Building where the place is suitable for walking the night air and there is an interesting view to be photographed. Many people take photos of Masjid Jamek from there. The place was named Masjid Jamek Lookout Point. We can walk along the riverbank to see the beautiful scenery of the blue river. There are also hood fish in certain parts in the small pool on the banks of the river. At the river meeting between the Klang River and the Gombak River, there is one waterfront with rhythmic water. There are 6 ethnic-based rhythms that can be witnessed at 9:15 a.m. and end at 11:00 a night so that from both banks of the river will glow blue.

\section{Conclusion}

Based on the results of the research and discussion, it can be concluded that public perception of the development of the River of Life area as one of the tourist attractions in Kuala Lumpur strongly agrees. The reason, River of Life revitalizes the old environment, also aims to increase the historic attractiveness of the 
city, providing an effective transformation network to ensure a pleasant journey for residents and tourists. Access to River of Life is very good. Through this project, the Kingdom has maintained the heritage buildings of the country by increasing the existing level of structure and increasing people's accessibility to the surrounding area. One of them is a pedestrian bridge that connects the mosque with the buildings of Sultan Abdul Samad and Dataran Merdeka which can shorten the travel time from before. The River of Life area can open new opportunities and jobs for the local community. River of Life will provide affordable housing for more than 35,000 new residents, one million square meters of commercial space, more than 27,000 new employment opportunities, increase use of public transportation in the master plan area from 15 per cent to $60 \%$ and reduce demand traffic by 15 per cent. River of Life as a tourist attraction that is different from the others and very unique. One component of the River of Life project is the Blue Pool or Blue Poll which is the River Beautification project which is located next to the Sultan Abdul Samad Building where the place is suitable for walking the night air and there is an interesting view to be photographed. We can walk along the banks of the river to see the beautiful scenery of the blue river. There are also hood fish in certain parts in the small pool on the banks of the river. At the river meeting between the Klang River and the Gombak River, there is one waterfront with rhythmic water.

\section{References}

Andriotis, K. 2005. Community Groups' Perceptions of and Preferences to Tourism Development. Evidence from Crete. Journal of Hospitality and Tourism Research, 29 (1): 67-90.

Dinnie, K, 2008. Nation Branding: Concept, Issues, Practice, pdf, Oxford, Great Britain, 23 Juli 2018 pukul 10.40 .

Ghanapala, W.K.A. 2015. Tourists perception and satisfaction: implications for destination management. American Journal of Marketing Research, 1(1), 7-19.

Halden, D. J. .2005, Measuring Accessibility as Experienced by Different Socially Disad-vantaged Groups, Funded by the EPSRC FIT Programme, Working Paper 3, Acces-sibility Analysis Literature Review, Trans-port Studies Group - University of West-minster. DHC Consultancy, Edinburgh, page 1-55. $<$ http://home.wmin.ac.uk/transport/download/SAMP_WP3_Accessibility__ Modelling.pdf $>$ $[06 / 06 / 10]$

Hermon, D., Khairani., Daswirman., S. Karim., Dasrizal., and Triyatno. 2008. Metode dan Teknik Penelitian Geografi Tanah: Aplikasi Instrumen dan Acuan Penelitian Geografi Fisik. Yayasan Jihadul Khair Center.

Hermon, D. 2009. Dinamika Permukiman dan Arahan Kebijakan Pengembangan Permukiman pada Kawasan Rawan Longsor di Kota Padang. Disertasi. IPB Bogor.

Hermon, D. 2010a. Geografi Lingkungan: Perubahan Lingkungan Global. UNP Press.

Hermon, D. 2010b. Arahan Kebijakan Pengembangan Permukiman pada Kawasan Rawan Longsor di Kota Padang. Jurnal SKALA. Vol. 1.

Hermon, D. 2012. Mitigasi Bencana Hidrometeorlogi: Banjir, Longsor, Degradasi Lahan, Ekologi, Kekeringan, dan Puting Beliung. UNP Press. Padang.

Hermon, D. 2015. Geografi Bencana Alam. Jakarta: PT RajaGrafindo Persada.

Hermon, D. 2016a. The Strategic Model of Tsunami Based in Coastal Ecotourism Development at Mandeh Regions, West Sumatera, Indonesia.Journal of Environment and Earth Science. Volume 6.

Hermon, D. 2016b. Mitigasi Perubahan Iklim. Rajawali Pers (Radjagrafindo).

Hermon, D. 2017. Climate Change Mitigation. Rajawali Pers (Radjagrafindo).

Hermon, D., Y. Suasti, Ernawati., Afdhal., and H. Edial. 2018. Geografi: Geografi untuk SMU. Jurusan Geografi Universitas Negeri Padang.

Jabatan pengairan dan saliran Malaysia, 2018. River Cleaning. Malaysia. Departement Of Irrigation and Drainage Malaysia. 
Kusmayadi, E.S. 2000. Metodologi Penelitian Dalam Bidang Pariwisata. Jakarta: PT. Gramedia Pustaka Utama.

Lanya. 1995. Buku Pedoman Kerja Pariwisata (BPKM) Mata Kuliah Dasar - Dasar Pengembangan Wilayah. Fakultas Pertanian Unud, Denpasar.

Mahmud, N. A. N. 2009. Konfrontasi Malaysia Indonesia. Bangi : Universiti Kebangsaan Malaysia.

March, R. 2004. A Marketing-Oriented Tool To assess Destination Competitive-ness, National Library of Australia Cata-loguing in Publication Data, CRC for Sus-tainable Tourism Pty Ltd, page 1-15, ISBN 1920704124.

Moli, G.P. 2011. Community Based Eco Cultural Heritage Tourism for Sustainable Development in the Asian Region: a Conceptual Framework. International Journal of Social Ecology and Sustainable Development (IJSESD). 2 (2). 66-80.

Nugraha, H.P., Indarjo, A. and Helmi, M. 2013. Studi Kesesuaian dan Daya Dukung Kawasan untuk Rekreasi Pantai di Pantai Panjang Kota Bengkulu. Journal of Marine Research, 2(2), 130-139.

Nyoman, S P. I. 1994. Ilmu Pariwisata Sebuah Pengantar Perdana. Jakarta : PT Pradnya Paramita.

Pike, S. 2004. Destination Marketing Organisations,USA, Netherlands: El-sevier, ISBN: 0-08-044306-0

Poerwadarminta. W.J.S. 2003. Kamus Umum Bahasa Indonesia. Jakarta : Balai Pustaka

Rajak, Najib 2017. Fasa 1 Pengindahan Sungai Projek River of Life. https://www.najibrazak.com/bm/blog/ fasa-1-pengindahan-sungai-projek-river-of-life/. Diakses tanggal 23 Juli 2018 pukul 10.33.

Richter, C. J. J. dan Rustidja. 1985. Pengantar Ilmu Reproduksi Ikan. Nuffic/ Unibraw/Luw/Fish, Malang.

Segaren, S. 2015. The River Of Life Project in Kuala Lumpur. http://www.expatgo.com/my/2015/05/14/ theriver-of-life-project-in-kuala-lumpur/. Diakses tanggal 24 Juli 2018 pukul 10.05.

Suwantoro, Gl. 2001. Dasar-dasar Pariwisata. Penerbit Andi. Yogyakarta.

Tjitroresmi, E, 2003. Peran Industri Kepariwisataan dalam Perekonomian Nasional dan Daerah. Jakarta: P2ELIPI.

Umar, I. 2017. Prioritas pengembangan Objek Wisata di Kota Padang, Provinsi Sumatera Barat. Volume 6 N0 1.

Walton, A.J. 2009. An Examination of The Relationship Between Employee Engagement and Organization Profitability Within European Manufacturing Units. Dissertation. Harold Abel School of Psychology: Capella University.

Yoeti, O.A. 1985. Pengantar Ilmu Pariwisata. Edisi Revisi. Bandung PT. Angkasa. 